\title{
National interests and the paradox of foreign aid under austerity: Conservative governments and the domestic politics of international development since $\mathbf{2 0 1 0}$
}

Keywords: foreign aid: DfID; Conservatives; austerity; Brexit; national interest

Acknowledgments: the ideas underpinning this paper have been informally discussed with a wide variety of colleagues, and I am grateful for their insights, although none are implicated in the final product. I would particularly like to thank the organisers (Nadia Molenaers, Joerg Faust and Jeroen Joly) and participants at 'The Domestic Dimensions of Development Cooperation', a conference at the Institute of Development Policy and Management University of Antwerp, Belgium October 24-25, 2016

\begin{abstract}
Since 2010, successive Conservative-led Coalition and Conservative governments in the UK have imposed domestic austerity while maintaining foreign aid commitments. They have done so in the teeth of considerable hostility from influential sections of the media, many Conservative MPs and party members, and large sections of the voting public. This paper explains this apparently paradoxical position by analysing these governments' increasingly explicit stance that aid serves 'the national interest' in a variety of ways. While not a new message from donors, post-2010 Conservative governments have significantly strengthened this narrative, with the (uncertain) intent of legitimising foreign aid expenditure.
\end{abstract}

\section{Introduction}

In 2010 a Conservative-led coalition with the Liberal Democrats displaced 'New Labour' from government in the United Kingdom after 13 years in power. In 2014, the Conservative Party achieved a narrow electoral majority to become the sole party of government. In 2016, following the Brexit referendum, a new Conservative government was formed under Prime Minister Theresa May. All three administrations have imposed/maintained deep budget cuts. The cuts have been justified as a necessary corrective to perceived New Labour profligacy, dangerously exposed by the global financial crisis (GFC). Critics, on the other hand, argue that austerity is being driven by an opportunistic, ideological restructuring of the British economy and society in the interests of deepening uneven capital accumulation 
(Kitson et al 2011; Hamnett 2014; Beatty and Fothergill 2014; Dorling 2015; Bale and Webb 2015). Puzzling, indeed angering to many, these governments chose to protect the foreign aid budget (more properly termed Overseas Development Assistance: ODA), to the extent that the UK met the historic commitment of $0.7 \%$ of Gross National Income (GNI) for the very first time in 2014. This was despite sustained hostility amongst many Conservative Members of Parliament (MPs), very influential sections of the media, and large numbers of the British public (Heppell and Lightfoot 2012; Tucket 2015). The commitment to UK foreign aid against a backdrop of painful austerity appears at first to present a considerable political paradox. Indeed, in a recent academic article examining public opinion and foreign aid cuts in the context of economic crises, Heinrich et al (2016) pick out the UK as an anomalous case amongst EU donors, and acknowledge that they are unable to explain why aid has been sustained. While current legislation commits UK governments to spending $0.7 \% \mathrm{GNI}$ on foreign aid, previous governments have failed to meet this target without facing particular sanction, and had they wished, recent Conservative governments could have pursued legislative change. The decision to ring fence ODA runs counter to arguments that foreign aid is an external projection of national redistribution inclinations and mechanisms, whereby higher levels of aid correlate with states that have higher commitments to domestic social welfare (e.g. Thérien and Noël 1994), which is certainly not true of current UK trends. Remarkably, the decision to honour the formal commitment to the $0.7 \%$ target (the question of how this is spent is a different question, and addressed later) was reaffirmed by Prime Minister May in April 2017. This is despite the fact that, in contrast to their respective predecessors, Prime Minister May and the Secretary of State for International Development, Priti Patel, have been comparatively unenthusiastic towards many forms of UK aid spending, and the role of DfID in particular. For the moment though, while substantive changes may take place within aid policy and expenditure, the insistence on aid serving the national interest is being made ever more explicitly under May and Patel.

The increasingly forceful insistence on aid serving the national interest is a corollary of the narrative that aid works in the mutual interests of the UK and its partners/recipients, something explored in depth by Keijzer and Lundsgaarde (2017). In other words, national interests are presented as aligned with donors 'doing good' in the world, in a 'win-win' projection more usually associated with South-South framings of development partnership. These claims to national interest are context dependent: they vary in relation to different parts of the aid portfolio, including domestic and overseas refugee spending, long term 
development commitments, private sector investments, conflict-related spending, and so on. Claims about the rationalities and realpolitik of aid are also pitched differently to different audiences - publics, parliamentarians, business people and so on. It should come as no surprise that their respective public justifications are diverse, or that claims that aid serves national interests are not new in practice or discourse. Donors have always pursued a variety of domestic interests through foreign aid and international development activities, some quite openly and some less transparently (Lancaster 2007; Milne and Tingley 2010; Essex 2013; Lundsgaarde 2013; Roberts 2014; Brown et al 2015; Hulme 2016; Kim and Gray 2016). This paper examines how and why the last three Conservative-led/Conservative governments have insisted on a much stronger and more explicit version of this narrative. The UK is not alone in this, but is reflective of an emphatic trend in wider foreign aid narratives discussed further in the conclusions (Breman 2011; Mawdsley 2015a; Keijzer and Lundsgaarde 2017).

The paper assumes the following conceptual conditions. The first is that there can be no singular or static account of the various norms and interests that shape policy decisions around foreign aid, not least because of its multidimensional nature: foreign aid takes many different forms, and performs many functions across different sites and scales (Glennie 2008). The second is that the institutional structures within which policy-making around foreign aid and development interventions take place are diverse and complex: aid establishments are not single actors or agents (Lancaster 2007; Essex 2014). Third, the context within which policy decisions take place are dynamic, rarely more so than at present. The international development landscape is in a moment of turbulent change due to the 'rising powers' and ascendency of South-South cooperation (UNDP 2013), the changing global geographies of poverty and wealth (Sumner and Mallett 2012), attempts by the established donors to move to a 'beyond aid' agenda (Janus et al 2014), and particularly for the UK, following the Brexit decision (Mendez-Parra et al 2016; Lightfoot et al 2017). ${ }^{1}$

The next section sets out a short account of the ways in which recent Conservativeled/Conservative governments have approached foreign aid and international development

\footnotetext{
${ }^{1}$ For Duncan Green's analysis in the immediate aftermath of Brexit, see: http://oxfamblogs.org/fp2p/whats-the-likely-impact-of-brexit-on-development-aid-and-oxfam-anyopportunities-amid-the-gloom/
} 
policy. ${ }^{2}$ The section that follows then examines in more detail their main stated rationales, as articulated within official aid policy documents, statements and speeches, with a focus on the interweaving claims about whether and how aid giving serves the UK's 'national interests' $^{3}$

\section{The Conservatives, UK aid and international development}

Within the Conservative Party - Ministers, MPs and members - there exist a range of views on the nature, purpose, value and effectiveness of foreign aid, and of the UK's proper role in the field of international development. Even so, since the founding of the Organisation for Economic Cooperation and Development's Development Assistance Committee (OECD-DAC) in 1960, official ODA contributions (when measured as a percentage of GNI) have always fallen under Conservative governments, sometimes slightly (e.g. 1970-74), sometimes more substantially (e.g. 1979-97). ${ }^{4}$ ODA fell under some Labour administrations too (1964-1970), but rose in other terms of office (1974-79; and notably over 1997-2010) (Barder 2005; Ireton 2013). The Conservative's 2009 Green Paper on international development (One World Conservatism: OWC) therefore signalled a significant change of perspective. OWC claimed that Labour governments wasted money, motivated by too much heart and not enough head, but said that they would do better, rather than retreat from the UK's commitments. It promised a more 'hard-headed' and 'value for money' approach which, it stated, would ensure that both British and partner country interests would be achieved. OWC committed a future Conservative government to meeting the $0.7 \% \mathrm{GNI}$ target, something that New Labour had not actually achieved. This was widely seen as demonstrating a new cross-party consensus on foreign aid and development, arising from an international context that included a renewed OECD-DAC and UN push on poverty reduction, notably through the Millennium Development Goals and the Paris Declaration process on greater aid effectiveness, strongly encouraged by a range of social and civil society voices, such as Make

\footnotetext{
${ }^{2}$ This paper is concerned with official UK ODA and development policy, and not with non-state actors, such as NGOs, foundations, faith-based organisations, peer giving/lending platforms or individuals. ${ }^{3}$ The paper is based on several years of research on various aspects of international aid politics, and UK aid in particular. Specific projects include research into the growing emphasis on private sector-led development, and on financialisation (funded through a Leverhulme Fellowship). A current project is the DfID/UK aid-India transition (funded by a Cambridge Humanities Research Grant). These projects have been conducted through extensive analysis of speeches and documents (such as DfID policy papers and Hansard's record of the International Development Committee meetings), and through a large number of interviews with past and present DfID and FCO staff, NGO representatives, and personnel in other development agencies.

${ }^{4}$ http://cf.owen.org/wp-content/uploads/UK-Aid-as-Share-GNI.png. Last accessed 4 July 2016.
} 
Poverty History. Hulme and Fukuda-Parr (2009) argue that the late 1990s and first decade of the 2000s marked a sea change in international aid and development norms, launching a significant new consensus on poverty reduction as the objective of the global development community. The Conservative Green Paper reflected this, even as it aimed to distance itself from New Labour through various claims and techniques.

When the Coalition came to power in 2010, Conservative MP Andrew Mitchell was appointed Secretary of State for International Development. The Liberal Democrats were represented by only one junior Minister in DfID, although Lynn Featherstone was widely seen as committed and effective in her role. Mitchell was an active and dedicated Minister who was influential in championing the role and status of DFID and UK aid (Heppell and Lightfoot 2012). He lost his position in 2012 due to a (controversial) scandal, and was replaced by Justine Greening, a Minister with a business and Treasury background. In the first Conservative-led Coalition government the support for foreign aid and British prominence in international development cannot therefore be attributed to pressure from the more progressive and socially-oriented Liberal Democrats (Hall-Matthews 2011).

While OWC was not an exact blueprint for the Coalition's aid policy after election, Glennie (2011) describes it as a serious statement of intent. In 2010 the new government announced that it would honour its promise that the UK would meet the $0.7 \%$ GNI UN target (which it did by 2014), and ring fence the international development budget (just under $£ 11.5$ billion in 2015). Foreign aid became one of only two spending areas protected from budget cuts. The other was the highly politically sensitive health budget; while more recently defence and the intelligence agencies have also seen greater protection. This was a quite remarkable decision, which took almost everyone by surprise, raising questions for some and provoking outright anger for others. Here it should be noted that ring-fencing the ODA budget is not the same as ring-fencing DfID's budget. In 2014, some 14\% of ODA was channelled outside of DFID, including through the FCO's Prosperity Fund (now re-badged as the CrossGovernment Prosperity Fund) and the Conflict Pool (National Audit Office 2015). However, to date at least, DfID continues to manage the bulk of ODA, and unlike some of its peers (e.g. in Australia, Canada, New Zealand) it has survived - thus far - as an independent agency.

One explanation for aid generosity is domestic image - particularly given concerns expressed before the 2010 election by the then shadow Home Secretary Theresa May, that 
the Conservatives needed to shed their image as the 'nasty party'. Julie Gallagher (2009, 2011) has detailed the ways in which Tony Blair sought to project his image as a moral leader and statesman through the UK's international development profile, notably in subSaharan Africa. However, such positive image building through a commitment to aid requires that a reasonable share of the domestic audience approve of the UK's development efforts, policy directions and narratives. During New Labour's terms of office there were criticisms and controversies (Marriage 2006; Taylor 2012), but it was a period of confident economic expansion and very active (if obviously contested) global engagement. The Blair and Brown years coincided with the launch of the Millennium Development Goals, the Make Poverty History campaign, and strong campaigns by faith-based movements, amongst others; and with the growth of popular celebrity developmentalism (Brockington 2014; Richey 2015). The UK's rich and vocal network of development organisations - think tanks, NGOs and academics amongst others - have been active in raising awareness and advocating for development issues with the general public, the private sector, and parliamentarians. Heppell and Lightfoot (2012) suggest that the early embrace of international development was partly an attempt to signal 'compassionate Conservatism'. But while many within the UK development community praised these governments for their ongoing commitments to international development, Prime Minister Cameron increasingly confronted a more complex national mood. Surveys attempting to measure public attitudes to development and/or to foreign aid are complex (Glennie et al 2012), and there are good reasons to be cautious about the rigour and credibility of some, or to assume that domestic economic contraction automatically reduces willingness to provide international assistance. Nonetheless, a review of a number of recent surveys suggests that public support for official UK contributions to international development is in decline. ${ }^{5}$ A 2014 Chatham HouseYouGov survey found that:

Although $30 \%$ of voters would hold aid spending at current levels, over half (54\%) of voters agree with the statement that the UK 'spends too much on aid. In difficult economic times we should spend more money at home.' The percentage rises to $62 \%$ among Conservative voters and $87 \%$ among UKIP voters, demonstrating the policy's unpopularity on the right of the electorate where the Conservatives are under pressure to defend their share of the vote from an ascendant UKIP. ${ }^{6}$

\footnotetext{
${ }^{5}$ Individual public generosity may remain high - it is important to delink these two phenomena.

${ }^{6}$ Available at: https://www.chathamhouse.org/expert/comment/15957. Last accessed 4 July 2016. One of UKIP's popular electoral commitments is that it will drastically cut ODA,
} 
Unlike Blair, Brown and Cameron, Theresa May had not shown any particular personal or political investment in foreign aid or international development before her commitment to the $0.7 \%$ target in April 2017. Indeed, her choice as Secretary of State for International Development, Priti Patel - someone who has been a tough critic of aid - appeared to signal a more hostile position, and perhaps the end of the cross-party consensus. Although Patel for the moment may have to commit to the $0.7 \%$ target, she had previously insinuated that she would not be driven by it. In the meantime, it is notable that Patel has robustly accelerated the 'national interest' agenda and narrative. She has announced significant increases to funding for the Commonwealth Development Corporation (CDC); announced that more UK ODA will be spent through Departments other than DfID, notably the Prosperity Fund; and is ever more strident in her insistence on the value of trade and investment as a development strategy, and the role that aid can play in leveraging this.

All three Conservative-led/Conservative governments have faced robust criticism from sections of the Party, the media and the public for their foreign aid commitments. The Daily Mail, for example, has led a vitriolic and sustained campaign against UK foreign aid. It articulates two main critiques: first, that aid is wasted in a variety of ways (e.g. corruption, supposedly 'daft' schemes, and aid going to countries like India which have domestic wealth and capacity); and second, that there is compelling need within the UK that should be given priority over spending abroad. Here the Mail runs into a dilemma given its equally if not more vitriolic campaign against many sections of Britain's poorest ('shirkers', 'benefit cheats' and so on), so it tends to focus on shortfalls in NHS funding, or more 'deserving' UK citizens. In 2014 the Mail led a campaign to re-direct foreign aid towards the thousands of people badly affected by severe flooding in South West England, gathering over 230,000 signatures in a parliamentary petition in three days alone, and generating considerable media debate (Tucket 2015). ${ }^{7}$ The Mail's impact should not be under-estimated - a number of DfID personnel interviewed over 2016/2017, wearily said that every decision was now framed by 'how will the Daily Mail present this'. Media criticism is not limited to the tabloids: The Sunday Telegraph ${ }^{8}$ and Economist magazine ${ }^{9}$ both frequently carry articles criticising various

http://www.ukip.org/ukip has reaffirmed its commitment to cutting the foreign aid budget by 9 billion. Last accessed 4 July 2016.

${ }^{7}$ For example: http://www.dailymail.co.uk/news/article-2559863/230-000-join-Mail-call-use-UKs11billion-foreign-aid-budget- tackle-floods-crisis.html Last accessed 28 June 2016.

${ }^{8}$ For example: http://www.telegraph.co.uk/comment/telegraph-view/10050587/We-need-honestyonforeign-aid-notring-fencing.html. Last accessed 28 June 2016. 
aspects of aid. Even supporters have expressed concern about the disjuncture between a protected foreign aid budget and massive cuts to social welfare given rising levels of poverty in the UK. ${ }^{10}$ Successive Conservative governments are acutely aware of these views, and the next section examines in detail how Conservative champions of foreign aid have sought to explain and defend it to different constituencies through recourse to an elevated insistence on the national interest, and accompanying policy changes.

\section{Conservative support for foreign aid and the 'national interest'}

Surveys and studies repeatedly show that public understandings of aid in the UK are dominated by the construction of it as 'charity': whether this is considered to be noble (benefitting poor people in poor countries) or naïve (wastefully benefitting corrupt leaders, business people and bureaucrats). This is an attitude that enrols a longer imperial and postimperial mind set (Duffield and Hewitt 2009; Noxolo 2012). At a global policy and governance level, since the late 1990s/early 2000s, the anti-poverty and aid effectiveness agenda has strongly promoted principles and mechanisms by which donors are meant to eschew narrow self-interest. Critical scholars, on the other hand, have for decades revealed the multiple ways in which foreign aid and development programmes have served various geopolitical and economic interests of donors. ${ }^{11}$ In some cases, these have been implicated

\footnotetext{
${ }^{9}$ For example: http://www.economist.com/news/international/21700323-development-aid-bestspent-poor-well-governed-countries-isnt-where-it. Last accessed 28 June 2016.

${ }^{10}$ Some analysts seem to reject this question purely on the basis that it is being asked by the Daily Mail, a right wing, populist tabloid newspaper. But it is a legitimate question to ask. This paper does not address the moral politics of aid in a context of enduring poverty in Britain (pre-dating the financial crisis, of course, but worsening under the last three governments). My short response would be that poverty in Britain is not caused by UK commitments to overseas aid, and nor would it be improved if foreign aid spending were to be reduced or cut. The causes of poverty in the UK are structural, created by past and present policy choices that impact on gendered, generational, regional, classed and ethnic (amongst others) inequalities and injustices. For a thoughtful analysis of UKIP and the Daily Mail's campaigns against foreign aid, and the sense of political abandonment felt by many working class men and women, see Tucket (2015).

${ }^{11}$ Something that I have heard regularly from friends and colleagues around the world is the assumption that British aid is at least partly stimulated by guilt or reparation for British colonial domination, violence and exploitation; or by the UK's more recent part in destabilising Afghanistan and Iraq, and the consequences there and elsewhere. Regrettably, there is no evidence that guilt is motivating the current official provision of UK aid. Indeed, in the 2009 Green Paper, the Empire is invoked with some pride (Noxolo 2012; see also Biccum 2005 on earlier iterations), while at no point have David Cameron, Justine Greening, Priti Patel or any official UK development-humanitarian spokesperson on the refugee crisis or the situation in Syria, for example, framed aid in terms of reparation for the UK's foreign policy misadventures. While there are plenty of claims around the morality of aid, these are couched in terms of 'doing right', and not as historical obligations or acknowledgement of guilt for more recent disastrous policy decisions.
} 
in destabilisation and conflict, facilitated neo-imperial extractivist regimes, propped up unsavoury allies, and eased the roll-out of neoliberal economic policies that have primarily served transnational capitalist elites (Rist 1997; Sogge 2002). But supporters of aid from across the ideological spectrum have also claimed a variety of ways in which foreign aid and international development policies and programmes legitimately act in donor interests. These include claims to a series of direct benefits: for example, that donor and recipient country citizens will benefit from prosperous and stable countries able to expand business with each other; and more diffuse global public goods - where aid supports, for example, climate change mitigation and adaptation, or aims to prevent potential health pandemics, or contribute to peace and security (Hulme 2016). While aid has all too often been tainted in its motivations and outcomes, there is nothing inherently contradictory in principle about 'winwin' outcomes or the mutual value of global public goods.

In the last few years there has been a palpable shift in official aid discourse across most, if not all, DAC donors, with DfID a leading example of a significantly more assertive and explicit discourse of foreign aid acting in 'national self-interest(s)' (Breman 2011). The reasons for this include the election of a series of right wing governments, growing populism and public discontent, the economic downturns that have followed the global financial crisis and Eurozone crisis, and an increasing sense of competition with the 'rising powers' (Mawdsley 2015a). In what follows, I examine the deepening efforts of Conservative champions of aid to justify expenditure in a time of austerity through reference to a variety of UK interests, namely soft power, global public goods, British economic interests, and security. Each one is claimed to represent a 'win-win' scenario for the UK and its partners.

First, all three Conservative-led/Conservative governments have identified UK soft power as an explicit benefit of foreign aid. The 2015 UK Aid policy (titled 'Tackling Global Challenges in the National Interest, and authored by HM Treasury as well as DFID) states:

UK leadership in [tackling poverty] will cement our global moral leadership, and make a strong contribution to the UK's soft power and our ability to project our influence across the globe (p.18). ${ }^{12}$

\footnotetext{
12 HM Treasury and DFID (2015) UK Aid: Tackling Global Challenges in the National Interest. https://www.gov.uk/government/uploads/system/uploads/attachment_data/file/478834/ODA_strat egy_final_web_0905.pdf
} 
DfID is widely admired by its peers in the industry as one of the world's leading development agencies (Morrissey 2002; Webster 2008; OECD 2010). It is large and relatively well funded in 2016 the UK was the second largest contributor of foreign aid in absolute terms, and the 5 th largest in terms of share of national income amongst OECD-DAC members, excluding the EU. Just as importantly, since its establishment in 1997, DfID has consistently sought to provide normative leadership at the international level. International development is a foreign policy arena within which the UK has been able to project itself, shaping debates and promoting UK interests and agendas. For example, in two Multilateral Aid Reviews (MARs), DfID has pursued a more open agenda of (stated) British national interests. As well as longestablished multilateral institutions, such as UN agencies, the OECD-DAC and Bretton Woods Organisations, there is a suite of newer and potentially highly strategic international forums and institutions opening up, with 'rising power' membership a key threat/incentive to join and assert influence. For example, the UK manoeuvred hard for Justine Greening to be one of the three Co-Chairs of the Global Partnership for Effective Development Cooperation, established in 2011. In this the UK was successful, and in the GPEDC's formative phase, the UK represented the 'established' donors with the two other Co-Chairs coming from Nigeria and Indonesia. In 2012 the Secretary General of the UN established a High-Level Panel of Eminent Persons on the Post-2015 Development Agenda, appointing David Cameron as one of the three Co-Chairs, together with President Ellen Johnson Sirleaf of Liberia and President Susilo Bambang Yudhoyono of Indonesia. These positions and others like them enable UK leaders, diplomats and civil servants to project direct and indirect influence over international norms, debates and policy statements. ${ }^{13}$ Were DfID to be downgraded and/or the aid budget to be substantially reduced, the UK would lose some of this external profile and leverage. Domestically, however, the UK government must contend with a nationalinternational disconnect. There is good evidence that a majority of the UK general public have very little awareness of what DIFD is, or what it does (Glennie et al 2012). The soft power rationale is more evident to government, policy and some business circles, but has limited purchase on the attitudes of the voting public (Otter 2003).

Second are global public goods, contributions to which can be framed as enlightened selfinterest. This is the intent to achieve outcomes such as climate change mitigation, human security, environmental sustainability, disease control, livelihoods and opportunities, good governance and so on in poor countries, with the primary or at least collateral outcome of

\footnotetext{
${ }^{13}$ This doesn't always mean the UK gets its way, of course. It was frustrated in efforts to shape the formation of the Sustainable Development Goals (SDGs) in particular ways, for example.
} 
reducing threats to and/or increasing UK interests. Current debates about global public goods in relation to the Sustainable Development Goals, for example, attempt to harness the potential alignments between national interests and the need to tackle global poverty, inequality and unsustainability (Hulme 2016). Classic examples include efforts to prevent the spread of communicable diseases, which in theory is good for those populations and countries at immediate risk, and good for a UK population at home and abroad who are at risk from epidemic outbreaks in a globalized world. This claim to enlightened self-interest is strongly made in the 2015 Aid Policy. The introduction by George Osborne and Justine Greening concludes: "With this new strategy, Britain can be proud to be a country that not only meets its responsibilities to the world's poorest, but in doing so best serves and protects its own security and interests" (UK Aid 2015: 4), and each of the four strategic objectives is couched in terms of helping others and benefitting the UK. This is not to say, of course, that these issues are well-handled. In the case of communicable diseases, for example, the enduring donor (state and major foundations) neglect - in some cases active dismantling - of comprehensive public healthcare systems continues to undermine meaningful and long term health transitions in many places (Biesma 2009; McGoey 2015). Claims to enlightened self-interest, it hardly need be said, can also conceal or gloss less worthy motivations. But leaving aside actual or intended outcomes, it is not politically implausible that the Conservative government would recognise the genuine national benefits of some forms of (supposedly progressive) global interventions (Sumner and Tribe 2011; Hulme 2016). Economic globalisation, transnational crime and climate change have all contributed to a growing acknowledgement that it is in the UK's interests to engage actively with these and other global issues, providing a credible explanation for some element of the Conservative governments' commitments to international development efforts.

Third, there are powerful economic rationalities for foreign aid (Essex 2014; Roberts 2015). This is not new - ODA has always served economic ends and interests, and to be clear, these are not inherently at odds with recipient interests. However, donor economic interests may not align with the goals of inclusive development, but result in short term profit-making, limited and unsustainable domestic economic linkages, extractive regimes, capital flight and so on. In the past, UK ODA was used illicitly to massage deals, the Pergau Dam in Malaysia being one particularly infamous example (Lankester 2013). ${ }^{14}$ Tied aid allowed donors to

\footnotetext{
${ }^{14}$ At the insistence of Margaret Thatcher and her Foreign Secretary Douglas Hurd, UK aid was used to fund the controversial Pergau Dam in Malaysia in order to secure a major arms deal. It was later found to have been an unlawful decision.
} 
make sure their firms benefitted from the domestic goods and services purchased through ODA. At a policy level, donor power within the institutions of global governance has enabled them to shape international policies (for example on the debt crisis and trade) in ways that protect and serve the interests of the powerful economies, for example in relation to capital controls and global tax norms. Under New Labour, and more broadly across the OECD-DAC members in the late 1990s and 2000s, some of these economic interests - many of which evidently clash with the aims of promoting poverty reduction and international development - became the subject of discussion and partial reform. The UK took the strong step of eliminating all tied aid in the 2002 International Development Act. Internationally, the Paris process sought to improve aid effectiveness, including by urging donors not to advance their own economic interests at the expense of recipient needs (OECD 2005). But while some progress was made, donors often fell short of full reform. Although the UK has performed better than many of its peers, it has been noted that British firms continue to win the vast majority of DfID contracts. ${ }^{15}$

The Conservative governments under discussion have emphatically embraced the idea of promoting economic growth as a core engine of development (Mawdsley 2015b). In 2013 DfID announced the creation of a new Director General for Economic Development, and released a Strategic Framework on economic development in 2014. ${ }^{16}$ Partnerships with the private sector are central to this vision (McGoey 2014), and in 2011 DfID created a new Private Sector Department. DfID is in tune with what appears to be a wider geo-economic turn in international development: the support that ODA can provide for donor firms and economic interests, for example through export credits, and by helping to de-risk expansion into 'frontier markets' (Carroll and Jarvis 2014), is now explicitly asserted as positive for all stakeholders. For example, Justine Greening was the first Secretary of State for International Development who has led a trade delegation, in this case to Tanzania. About this she said:

\footnotetext{
${ }^{15}$ https://www.theguardian.com/global-development/datablog/2012/sep/21/why-is-uk-aid-going-touk-companies. Last accessed 4 July 2016. See also Mark Tran "DfID's aid spend on contractors comes under scrutiny", The Guardian, Friday 17 May 2013, available at http://www.theguardian.com/globaldevelopment/2013/may/17/DfID-aid-contractors-scrutiny (accessed 6 March 2015). ${ }^{16}$ DfID, "Economic Development for Shared Prosperity and Poverty Reduction: A Strategic Framework" (2014), available: https://www.gov.uk/government/uploads/system/uploads/attachment_data/file/276859/Econdevelopment-strategic-framework_.pdf
} 
As a British Minister I make no apology for flying the flag in these frontier markets.

My Department should be flying the flag like every other bit of government. ${ }^{17}$

The economic benefit to the UK - while claiming positive outcomes for poorer people and partner countries - is one of the key ways in which all three Conservative governments have insisted that UK foreign aid acts 'firmly in the national interest'. While this paper does not assess these claims in depth, we can note three critical responses. The first comes from Glennie et al (2012), who suggest that the 'British self-interest' message may in fact not appeal strongly to large sections of the public, who instead continue to frame aid in moral terms. Second are those critics who ask whether these policies are indeed having positive impacts on poverty reduction and development, or whether they are simply contributing to uneven and unsustainable growth within partner countries, with little or no benefit tricking down to poorer people or places (Tomlinson 2012). The third comes from Murray and Overton (2016), who unpack the 'national' in 'national interest'. They observe that in New Zealand and beyond, including the UK, ${ }^{18}$ ODA is increasingly being directed towards the corporate and financial sectors. In other words, ODA is contributing to dual domestic economic strategies: austerity for the majority (and most harshly, the poor and marginalised), while providing quantitative easing, export credits and de-risking for the corporate sector. Murray and Overton (2016) suggest that some parts of the ODA portfolio are being used to contribute to 'stimulus' packages directed upwards, while cuts are directed downwards. Where this departs from previous decades of tied aid and economic self-interest is in the shift in sectoral benefits. Earlier tied aid helped promote markets for British manufacturers, for example, of weapons or agricultural machinery. Leaving aside the ethics of this, in this era there was arguably a greater spread of benefits for British workers. Today's aid is formally untied, but a greater share of ODA is being directed through management consultants and financial services firms (Mawdsley 2017). The economic benefits of foreign aid as stimulus are more likely to be dragged upwards by well-paid professionals and firms, and the profits off-shored.

\footnotetext{
${ }^{17}$ Greening (2014) https://www.gov.uk/government/speeches/smart-aid-why-its-all-about-jobs. Last accessed 5 July 2016.

${ }^{18}$ Mawdsley, E., Murray, W., Overton, J., Scheyvens, R. and Banks, G. "Exporting Stimulus and 'Shared Prosperity': Re-Inventing Foreign Aid for a Retroliberal Era", Working Paper (New Zealand Aid and Development Dialogues, 2015), available: <at http://nzadds.org.nz/>
} 
Finally, an enduring claim to national interest is based on security. As with the economic agenda outlined above, ODA has long served geopolitical ends - that is, the primary or collateral aim to influence foreign affairs in ways that support (presumed) 'national' security and other foreign policy interests. The subservience (although never complete dominance) of foreign aid in Cold War geopolitical contestation has been analysed in depth (e.g. Simpson 2008), while other long-standing and more recent geopolitical contexts and drivers of aid policies include UK support for 'friendly' regimes in the Middle East, development activities in Afghanistan, and other 'post-conflict' sites of strategic interest (e.g. Waddell 2006; Duffield 2007; Curtis 2013). All three Conservative governments have made strong and unapologetic statements about foreign aid being used in British security interests, although always with the accompanying claim that it is also doing 'good' for those communities and countries being targeted. In 2010 the government created a National Security Council, comprised of the Ministry of Defence (MOD), the Foreign and Commonwealth Office (FCO), and as junior partner, the Department for International Development (DfID). ${ }^{19}$ The first of the four strategic objectives listed in the 2015 Aid Strategy is:

Strengthening global peace, security and governance: the government will invest more to tackle the causes of instability, insecurity and conflict, and to tackle crime and corruption. This is fundamental to poverty reduction overseas, and will also strengthen our own national security at home.

Again, while not new, recent Conservative governments have deepened the securitydevelopment aid nexus, and pushed this message very strongly. In 2015 , for example, in his high-profile Lord Mayor's Banquet Speech, David Cameron announced that 50\% of DFID's budget must be allocated to developing 'fragile and failing states' as part of a 'full spectrum' response to the terrorist threats. The previous year this line of spending had come to $30 \%$ of DfID's budget, requiring a significant (around $£ 3.5$ billion) allocation from elsewhere in its budget.

\section{Conclusions}

Conservative governments are currently subject to legislative requirements that they allocate $0.7 \% \mathrm{GNI}$ as Overseas Development Assistance, but clearly this is not enough to

\footnotetext{
${ }^{19}$ Whitehall politics are always more complicated than the formal institutional architecture may suggest. DfID's relatively more secure budget gives it greater leverage in some contexts than might be at first apparent.
} 
explain their commitment to what is a deeply unpopular policy for many of their supporters. The resolution to the apparent paradox is not in fact all that hard to identify. Under David Cameron, Andrew Mitchell, Justine Greening, and now Priti Patel and Theresa May, aid has been increasingly diverted and re-worked to serve more openly (so-called) 'national interests'. Some of these are long-standing, but are adapting to new contexts. In the case of 'soft power', for example, DfID has sought leading roles and influence within new forums opening up with the rising powers, multilaterally (for example, the Global Partnership for Effective Development Cooperation) and bilaterally (for example, as it adjusts its relationships with India and China). Aid provides financial resources to tackle global public goods issues, ever more pressing in an increasingly globalised world. In security, ODA is a major source of the UK's financing of domestic and overseas refugee spending in the fall out from the Syria crisis, for example. The accelerating and deepening relationship between aid and capital has been striking under recent Conservative governments. Using public money to escort private capital out to 'frontier economies' (Carroll and Jarvis 2014) and de-risk UK investment is entirely in keeping with bailouts for the banks and cuts to social services. Instruments include the Commonwealth Development Corporation (CDC), the Prosperity Fund and a DfID increasingly tuned to promoting growth can act in support of neomercantilist support for British firms and investors. It is significant that a higher proportion of ODA is being directed into other government departments, including defence, border forces, business and research. ${ }^{20}$

In June 2016 Britain voted by a narrow margin to leave the EU. The UK is now entering a period of extraordinary, indeed chaotic, domestic politics. Theresa May is further to the right than Cameron, and the economic uncertainties of the Brexit process will put further pressure on the UK's budget. Despite the rationales outlined above, which to different extents are aligned and compatible with Conservative agendas of domestic austerity and support for corporate/financial sectors, soft power and security interests, the UK ODA budget is highly vulnerable. ${ }^{21}$ For better or worse (and this paper has not attempted to ask whether the UK should give aid, or whether aid is effective in achieving poverty reduction

\footnotetext{
${ }^{20}$ The recent establishment of the Global Challenges Research Fund (GCRF), for example, has committed $\mathrm{f1.5}$ billion of the ODA budget for (UK-dominated) research into 'global challenges'. The jury is out on whether this will have structural, desirable, transformative and sustainable impacts on poor people in poor countries, but the jury is in on the benefits that will stream to UK universities and related institutions.

${ }^{21}$ For initial responses to what Brexit might mean for partners and recipients, trade and global development trends, see Owen Barder: http://www.cgdev.org/blog/brexit-threats-and-opportunitiesglobal-development. The ODI has also run events and publications.
} 
and sustainable development, or indeed, of acting in narrow national interests), aid will continue to be a target for many critics. It is significant then, that in April 2017, Theresa May reaffirmed the UK's commitment to the $0.7 \%$ target, amid a flurry of speculation that she would dispense with it, and a series of counter-interventions from the likes of Bill Gates and the President of the World Bank encouraging her to keep to it. ${ }^{22}$ The major tension arises from the substantial disconnect between public and influential media conceptions of what aid is and what it achieves, and the strategic purposes it actually serves. Foreign aid is not an 'easy sell' given weak public and media understandings of the many ways in which aid works - soft power, economic advantage and geopolitical influence; and given the context of deep spending cuts in other parts of the national budget. Moreover, there is evidence from several contexts, including the UK (Glennie 2008) and Australia ${ }^{23}$, that scripting aid in ways that seem to put national interests first is not inevitably popular with the majority of voters. Successive Conservative-led and Conservative governments have appealed to the public's moral/charitable instincts with reference to achievements in providing education, food and water (for example) for the world's poorest and most vulnerable. But they have also increasingly explicitly attempted to persuade domestic audiences that aid works in the 'national interest(s)', and indeed, have pursued policy and modality shifts in these directions. Whether Conservative champions can persuade the public, party and media that aid should and does work in their interests remains a pressing political question.

\section{References}

Bale, T. and Webb, P. (2015) The Conservatives: Their Sweetest Victory?, Parliamentary Affairs, 68 (1), 41-53.

Barder, O. (2005) Reforming Development Assistance: Lessons from the UK Experience, Centre for Global Development Working Paper 70 (October 2005).

Beatty, C. and Fothergill, S. (2014) The local and regional impact of the UK's welfare reforms. Cambridge Journal of Regions, Economy and Society, 7 (1), 63-79

\footnotetext{
${ }^{22}$ See, for example: https://research.aston.ac.uk/portal/en/researchoutput/brexit-and-ukinternational-development-policy(f495a702-672d-4070-869c-8859f1f6bf49).html. Last accessed 27 April 2017.

${ }^{23} \mathrm{http} / / /$ devpolicy.org/want-sell-aid-australian-public-values-not-national-interests-20170323/
} 
Biccum, A. R. (2005) Development and the 'New' Imperialism: A reinvention of colonial discourse in DfID promotional literature, Third World Quarterly 26(6): 1005-1020.

Biesma, RG, Brugha, R, Harmer A., Walsh A., Spicer N, and Walt, G. (2009) The effects of global health initiatives on country health systems: a review of the evidence from HIV/AIDS control, Health Policy Plan. 24 (4): 239-252

Breman, J. (2011) A Change for the Better? Dutch Development Aid in the Good Times and Bad Times. Review Essay. Development and Change, 42 (3), 833-48.

Brockington, D. (2014) Celebrity Advocacy and International Development. London and New York: Routledge.

Brown, S., den Heyer, M and Black, R. (2015) Rethinking Canadian Aid. University of Ottowa Press.

Cameron, D. (2011) Why we're right to ring fence the aid budget. The Guardian, 11 June 2011. Available at: http://www.theguardian.com/global-development/2011/jun/11/davidcameron- defends-aid-funding

Carroll T and Jarvis DSL (2014) Financialisation and Development in Asia. London: Routledge.

Curtis, D. (2013) China and the Insecurity of Development in the Democratic Republic of the Congo (DRC), International Peacekeeping, Vol. 20, No. 5 (2013)

Davies, P. (2013) Overseas Aid is a Failed Policy - We should put our own people first. Conservative Home Blog, 3 September 2013. Available at: http://www.conservativehome.com/platform/2013/09/from-philipdaviesmp.html DfID (2008) Private Sector Development Strategy, Prosperity for All: Making Markets Work, London: DfID DfID (2011) The Engine of Development: The Private Sector and Prosperity for Poor People London: DfID 
Dorling, D. (2015) Income inequality in the UK: Comparisons with five large Western European countries and the USA. Applied Geography 61, 21-34

Duffield, M. (2007) Development, Security and Unending War, Cambridge: Polity Press.

Duffield, M. and Hewitt, V. (eds.) (2009) Empire, Development and Colonialism: the Past in the Present (James Currey)

Dunne, M, Hall-Matthews D, and Lightfoot S. (2011) 'Our Aid': UK International Development Policy under the Coalition. Political Insight 2, no. 1: 29-31.

Essex, J. (2013) Development, Security, and Aid Geopolitics and Geoeconomics at the U.S. Agency for International Development. University of Georgia Press.

Gallagher, J. (2011) Britain and Africa under Blair: In pursuit of the good state. University of Manchester Press.

Gallagher, J. (2009) Healing the Scar: Idealising Britain in Africa, 1997-2007, African Affairs, Vol. 108, No. 432 (2009), pp. 435-451.

Glennie, J. (2008) The trouble with aid: why less could mean more for Africa. London: Zed Books

Glennie, J. (2011) From Green Paper to Government: The Coalition's Record on international development, Area 43 (4), 508-9

Glennie, A., Straw, W. and Wild, L. (2012) Understanding public attitudes to aid and development. London: IPPR and ODI

Hall-Matthews, D. (2011) Liberal Democrat influence on coalition international development policy. Area 43:4, 511-512 
Hamnett, C. (2014) Shrinking the welfare state: the structure, geography and impact of British government benefit cuts. Transactions of the Institute of British Geographers, 39 (4), 490-503.

Heinrich, T., Kobayashi, Y. and Bryant, KA (2016) Public Opinion and Foreign Aid Cuts in Economic Crises. World Development 31 (1), 66-79.

Heppell, T. and Lightfoot, S. (2012) "We Wil not back the books on the backs of the poorest people in the world": understanding Conservative Party strategy on international aid. The Political Quarterly. 83:1, 130-138

Hudson, D. and van Heerde-Hudson, J. (2012) A Mile Wide and an Inch Deep': Surveys of Public Attitudes Towards Development Aid. International Journal of Development Education and Global Learning, 4 (1): 5-23

Hulme, D. (2016) Should Rich Nations Help the Poor? Polity.

Institute of Development Studies (2010). Public Perceptions of International Development and Support for Aid in the UK: Results of a Qualitative Enquiry. Working Paper. London.

Ireton, B. (2013) Britain's International Development Policies: A History of DfID and Overseas Aid, Basingstoke: Palgrave Macmillan.

Janus, H., S. Klingebiel and S. Paulo (2014) Beyond Aid: A Conceptual Perspective of the Transformation of Development Cooperation", Journal of International Development 27 (2) 155-69

Keijzer, N. and Lundsgaarde, E. (2017) When Unintended Effects become Intended: Implications of 'Mutual Benefit' Discourses for Development Studies and Evaluation Practices. Working Paper: Ministry of Foreign Affairs of the Netherlands, and Radboud University.

Killick, T (2005) Policy Autonomy and the History of British Aid to Africa. Development Policy Review, 23 (6), 665-681. 
Kim, S. and Gray, K. (2016) Overseas Development as Spatial Fix? Examining South Korea's Africa Policy. Third World Quarterly, 37 (4), 647-64

Kitson, M, Martin, R. \& Tyler, P. (2011) The Geographies of Austerity. Economy and Society $4: 3,289-302$

Lancaster, C. (2007) Foreign aid: diplomacy, development, domestic politics. Chicago: University of Chicago Press

Lankester, T. (2013) The Politics and Economics of Britain's Foreign Aid: The Pergau Dam Affair

Lightfoot, S., Mawdsley, E. and Szent-Iványi, B. (2017) Brexit and UK International Development Policy. The Political Quarterly. Available online:

https://research.aston.ac.uk/portal/en/researchoutput/brexit-and-uk-internationaldevelopment-policy(f495a702-672d-4070-869c-8859f1f6bf49).html. Last accessed 27 April 2017.

Lundsgaarde, E. (2013) The Domestic Politics of Foreign Aid, USA: Edwards Brothers Malloy.

Marriage, Z. (2006) Defining Morality: DfID and the Great Lakes, Third World Quarterly, Vol. 27, No. 3 (2006), pp. 477-490.

Mawdsley, E. (2011) The Conservatives, the Coalition and international development. Area 43:4, 506-507

Mawdsley, E. (2015a) Development Progress Report I: Cooperation, competition and convergence between 'North' and 'South' in international development: Provincialising Development? Progress in Human Geography

Mawdsley, E. (2015b) DfID, the private sector, and the re-centring of an economic growth agenda in international development, Global Society 29(3), 339-58. 
Mawdsley, E. (2017) ‘Development Progress Report II: Financialisation and Development'. Progress in Human Geography.

McGoey, L. (2014) The philanthropic state: market-state hybrids in the philanthrocapitalist turn. Third World Quarterly 35 (1), 109-25

McGoey, L. (2015) No Such Thing as a Free Gift: The Gates Foundation and the Price of Philanthropy. Verso Books.

Mendez-Parra, M., te Velde, DW, and Winters, AL (2016) The Impact of the UK's post-Brexit trade policy on development. Overseas Development Institute.

Milner, HV and Tingley, VH (2010) The political economy of US foreign aid: American legislators and the domestic politics of aid. Economy and Politics 22 (2), 200-31

Morrissey, O. (2002) British aid policy since 1997: is DfID the standard bearer for donors? CREDIT Research Paper No. 02/23

Murray, W. and Overton, J. (2016) Retroliberalism and the new aid regime of the 2010s. Progress in Development Studies, May 23 2016, doi 1464993416641576

National Audit Office (2015) Trends in total UK Official Development Assistance and the Department for International Development's expenditure. UK Government.

Noxolo, P. (2012) One world, big society: a discursive analysis of the Conservative green paper for international development. Geographical Journal 178 (1), 31-41

OECD (2005) Paris Declaration on Aid Effectiveness. OECD: Paris.

OECD- DAC Peer Review (2010) The United Kingdom. Paris: OECD.

Otter, M. (2007) Domestic public support for foreign aid: does it matter? Third World Quarterly 24:1, 115-125 
Porteous, T. (2005) “British Government Policy in Sub-Saharan Africa under New Labour", International Affairs, Vol. 81, No. 2, pp. 281-297.

Richey, Lisa Ann, ed. (2015) Celebrity Humanitarianism and North-South Relations: Politics, Place and Power. Routledge

Rist, G. (1997). The History of Development: From Western Origins to Global Faith. Zed Books, London.

Roberts, SM (2014) Development Capital: USAID and the Rise of Development Contractors, Annals of the Association of American Geographers, Vol. 105, No. 5 (2014), pp. 1030-1051.

Sharp, J., Campbell, P., and Laurie, E. (2010) The violence of aid? Giving, power and active subjects in One World Conservatism. Third World Quarterly, 31(7), pp. 1125-1143.

Simpson, B. (2008) Economists With Guns: Authoritarian Development and U.S.-Indonesian Relations, 1960-1968. Stanford: Stanford University Press.

Sogge, D. (2002) Give and Take: What's the matter with foreign aid? New York and London: Zed Books

Sumner, A. \& Tribe, M. (2011) The case for aid in fiscally constrained times: morals, ethics and economics. Journal of International development 23:6, 782-801

Sumner, A. and Mallett, R. (2012) The Future of Foreign Aid: Development Cooperation and the New Geography of Global Poverty. Palgrave Macmillan.

Taylor, I (2012) Spinderella on Safari: British Policies toward Africa Under New Labour, Global Governance: A Review of Multilateralism and International Organizations, Vol. 18, No. 4 (October-December 2012), pp. 449-460.

Thérien, J. and Noël, A. (1994) Welfare institutions and foreign aid: Domestic foundations of Canadian foreign policy. Canadian Journal of Political Science, 27(3), pp.529-558. 
Tomlinson, B. (ed.) (2012) Aid and the Private Sector: Catalysing Poverty Reduction and Development? Reality of Aid, Philippines: IBON International

Tucket, M. (2015) 'Take care at home first': Working Class Uncertainties and Foreign Aid Spending in Britain. Masters dissertation, University of Manchester.

UNDP (2013) Human Development Report: The Rise of the South - Human Progress in a Diverse World. New York: UNDP.

Waddell, N. (2006) "Ties that bind: DfID and the emerging security and development agenda", Conflict, Security and Development 6 (4), 531-55.

Webster, A. (2008) New Labour, new aid? A quantitative examination of the Department for International Development. International Public Policy Review. 4:1, 1-28 